\title{
FIELD STUDIES OF BOTTOM CREVASSES IN THE ROSS ICE SHELF, ANTARCTICA*
}

\author{
By Kenneth C. Jezek and Charles R. Bentley \\ (Geophysical and Polar Research Center, University of Wisconsin-Madison, Madison, \\ Wisconsin 53706, U.S.A.)
}

\begin{abstract}
Surface and airborne radar sounding data were used to identify and map fields of bottom crevasses on the Ross Ice Shelf. Two major concentrations of crevasses were found, one along the grid-eastern grounding line and another, made up of eight smaller sites, grid west of Crary Ice Rise. Based upon an analysis of bottom crevasse heights and locations, and of the strength of radar waves diffracted from the apex and bottom corners of the crevasses, we conclude that the crevasses are formed at discrete locations on the ice shelf. By comparing the locations of crevasse formation with ice thickness and bottom topography, we conclude that most of the crevasse sites are associated with ice rises. Hence we have postulated that six ice rises, in addition to Crary Ice Rise and Roosevelt Island, exist in the grid-western sector of the ice shelf. These "pinning points" may be important for interpreting the dynamics of the West Antarctic ice sheet.
\end{abstract}

RÉSumÉ. Études sur place des crevasses de fond dans le Ross Ice Shelf, en Antarctique. On a utilisé des résultats de sondages radar aériens et terrestres pour identifier et cartographier les réseaux de crevasses de fond dans le Ross Ice Shelf. On a trouvé deux principales concentrations de ces crevasses, l'une le long de la ligne de décollement orientale et l'autre faite de huit petits emplacements à la lisière Ouest du Crary Ice Rise. Une analyse des hauteurs et des localisations des crevasses de fond et de l'intensité des réflexions radar diffusées par les sommets et les bords inférieurs des crevasses nous permet de conclure à leur formation en des points précis de la plateforme. En comparant les localisations des formations de crevasses avec l'épaisseur de la glace et la topographie du fond, nous concluons que la plupart des zones de crevasses sont associées à des zones de surrection de la glace. Nous en avons déduit qu'il pouvait exister six points de surrection de glace, en sus du Crary Ice Rise et de Roosevelt Island, dans le secteur Ouest de la plateforme glaciaire. Ces zones de "pointements" peuvent être importantes pour interpréter la dynamique de la calotte glaciaire Ouest Antarctique

Zusammenfassung. Felduntersuchungen an Spalten am Untergrund des Ross Ice Shelf, Antarktika. Zur Auffindung und Kartierung von Spaltenfeldern am Untergrund des Ross Ice Shelf wurden Radar-Sondierungen auf der Oberfläche und aus der Luft verwendet. Es fanden sich zwei grössere Spaltenkonzentrationen: eine längs der ostwärts verlaufenden Absetzlinie und eine andere, zusammengesetzt aus acht kleineren Feldern, westlich von Crary Ice Rise. Auf der Grundlage einer Analyse der Höhen und Lagen der Untergrundspalten sowie der Stärke von Radarwellen die an den Scheiteln und Unterkanten der Spalten gestreut wurden, lässt sich schliessen, dass die Spalten an verschiedenen Stellen des Schelfeises gebildet wurden. Aus dem Vergleich der Stellen, an denen Spaltenbildung eintritt, mit der Eisdicke und der Untergrundsform folgt, dass der Grossteil der Spaltenfelder mit Eiserhebungen verbunden ist. Daraus lässt sich ableiten, dass sechs Eiserhebungen, zusätzlich zum Crary Ice Rise und zu Roosevelt Island, im westlichen Sektor des Schelfeises vorhanden sind. Diese „Nadelpunkte” dürften für die Interpretation der Bewegung des westantarkischen Eisschildes von Bedeutung sein.

\section{INTRODUCTION}

Surface and airborne radar soundings of the Ross Ice Shelf have been used to identify and map bottom-crevasse fields as part of the Ross Ice Shelf Geophysical and Glaciological Survey (RIGGS). Particularly detailed surveys were carried out on the surface at the four RIGGS base camps and at $\mathrm{J} 9$ (lat. $7^{\circ} 29^{\prime} \mathrm{S}$., long. $1^{\circ} 5^{\prime} \mathrm{W}$.; all coordinates are referenced to the grid system), where a rigorous analysis of the data has revealed a complex distribution of bottom crevasses. These data provide an accurate determination of crevasse positions along with details about

* Geophysical and Polar Research Center, University of Wisconsin-Madison, Contribution No. 394. 
bottom-crevasse heights, shapes, and their effect on overlying ice (Jezek and others, 1978); in addition, experiments with a short-pulse radar, used to probe the near surface, indicate that there are also relict surface crevasses preserved at $\mathbf{J} 9$ (Jezek, unpublished). A similar survey was carried out by Clough (1974) at RIGGS camp B.C. (lat. $7^{\circ} 14^{\prime}$ S., long. $1^{\circ} 48^{\prime}$ W.); a reevaluation of the data from this site suggests that bottom crevasses are distributed in a pattern similar to that at J9, although the crevasses at B.C. are slightly larger than those at J9 (Jezek, unpublished).

A rough idea of the distribution of bottom-crevasse fields over the entire ice shelf can be obtained by examining RIGGS radar data collected on the surface at the remote stations (Jezek unpublished). However, the separation between these stations was too large to permit any firm conclusions to be drawn, so we have also examined the data collected during the NSF-SPRI-TUD radar flights. These data have revealed two major concentrations of bottom crevasses. Large crevasses open along the grounding line between East Antarctic outlet glaciers. Another complex distribution of bottom crevasses extends over a wide ice-flow band flanked by the grid-eastern margin of Ice Stream B and the grid-north-eastern margin of Ice Stream C.

Crevasses along the grid-eastern grounding line of the ice shelf are probably caused by a combination of stress - tidal flexure and shear stress - between the outlet glaciers and adjacent zones of slower-moving ice. Some of the bottom crevasses in the grid-western flow band are believed to be caused by ice rises: crevasses form as a reponse to stresses exerted on the ice shelf as it encounters the ice rise.

\section{ANALYSIS}

Bottom crevasses appear on the radar records as trios of hyperbolas representing diffracted arrivals off the apex and bottom corners of wedge-shaped crevasses (Fig. 1). We have found that bottom crevasses appear in distinct groups composed of numerous individual crevasses. Because

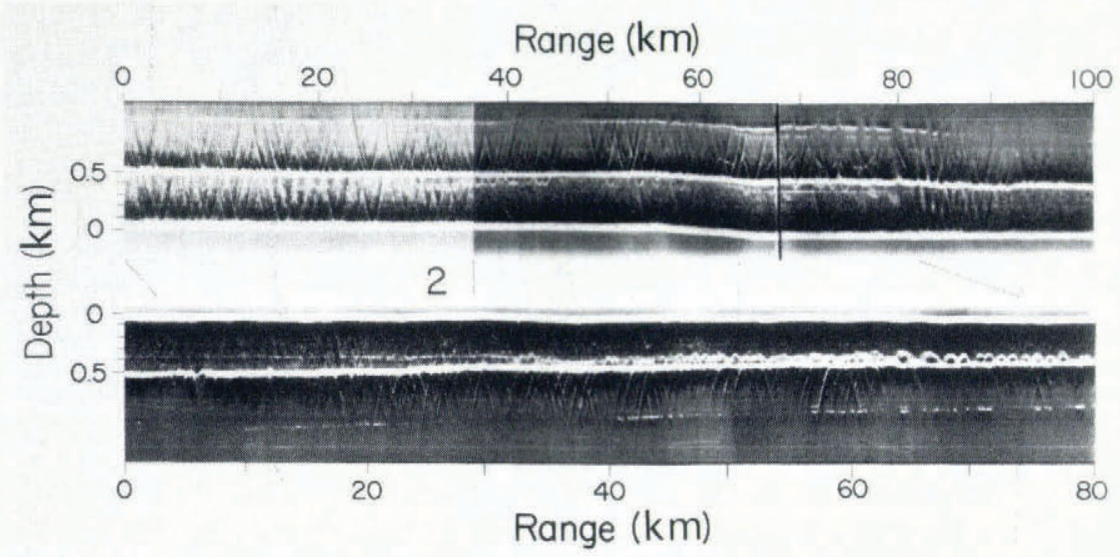

Fig. 1. Sections of radar echograms showing the crevasse field which includes the J9 and B.C. areas (group 2 in Fig. 2). The coordinates of the data starting in the upper left-hand corner of the figure are lat. $2^{\circ} 9^{\prime} W$., long. $6^{\circ} 45^{\prime} \mathrm{S}$. The upper record has been inverted to maintain the sense of the east-west direction between records. The line segments connect points on the records which fall on common flow lines. The crevasses which appear at about $60 \mathrm{~km}$ in the lower record are the group 4 crevasses in Figure 2. 
the density of crevasses in most groups was generally too high to map each crevasse individually, only zones of crevasses, having roughly uniform heights, were mapped (Fig. 2).

Most of the crevasses occur along the grounding line between East Antarctic outlet glaciers, and in a band of ice consisting of the outflow of Ice Stream B and the grid-eastern margin of Ice Stream C (Fig. 2). The largest crevasses along the grid-eastern grounding line are about $220 \mathrm{~m}$ high. Large crevasses rapidly disappear down-stream and no major crevasse fields appear in the south-eastern quadrant of the map, although crevasses less than $50 \mathrm{~m}$ high persist to the barrier. Larger crevasses open between the outlet glaciers and, in fact, penetrate up into the permeable layers of ice allowing brine to percolate outwards into a layer (Neal, 1979). The brine masks the crevasses below, hence the region where they form cannot be accurately determined. Since we are interested in understanding why crevasses form, these clearly remnant crevasses were not mapped.

Crevassing in the grid west is more complicated. There are at least eight sites of active crevasse formation in the flow band limited by the margin of Ice Streams B and C. At least three smaller sites are found farther to the grid west. The locations where the eleven groups of bottom crevasses first appear are numbered on the map (Fig. 2).

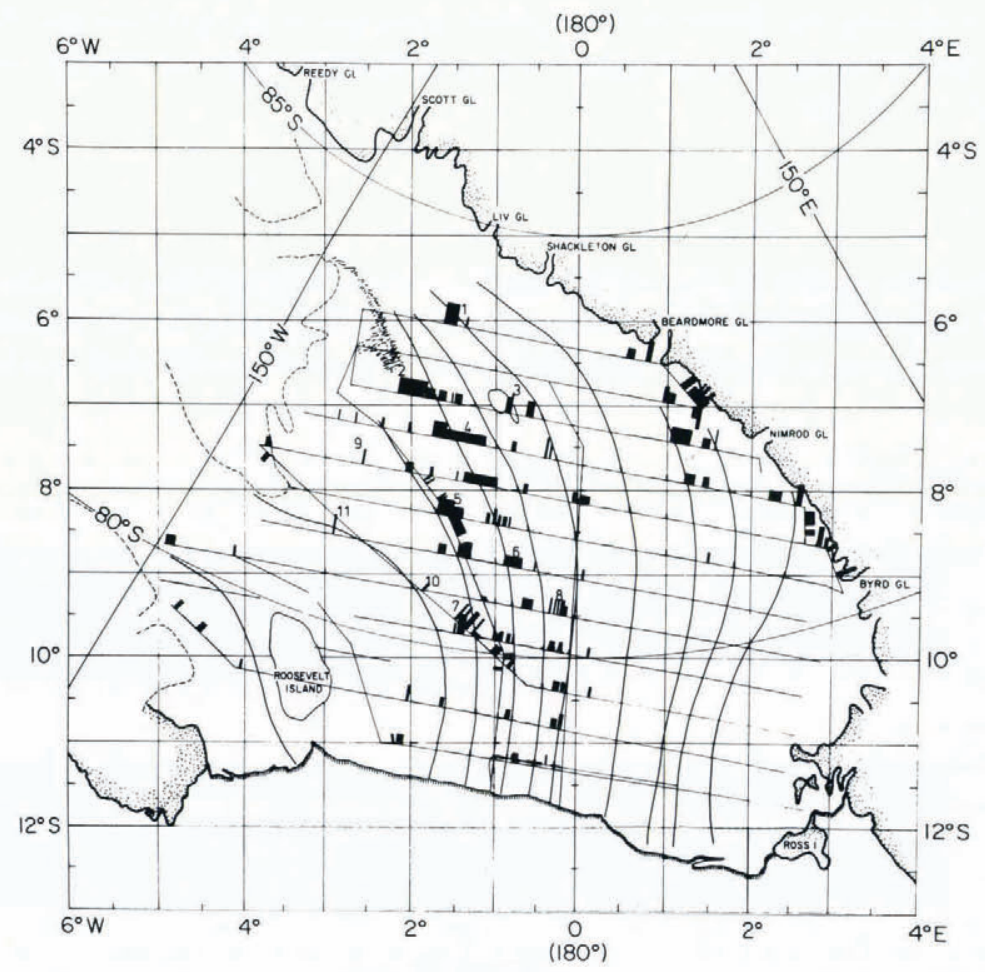

Fig. 2. Bottom-crevasse map of the Ross Ice Shelf. Thin lines represent flight tracks of the NSF-SPRI-TUD airborne radar program along which data used in this paper were collected. Heavy lines represent flow lines inferred from velocity measurements made by U.S.G.S. during RIGGS. Crevasses have been mapped by height as well as location. The height ranges, signified by the heights of the blocks along the flight tracks, are less than $50 \mathrm{~m}$, $50-100 \mathrm{~m}, 100-150 \mathrm{~m}$, and greater than $150 \mathrm{~m}$. Eleven groups of crevasses have been identified in the gridwestern sector of the map and are identified by number. 
Isolated groups of large crevasses occur at locations 1, 3, and 7. Crevasses in these groups penetrate 160,200 , and $200 \mathrm{~m}$ up into the base of the ice shelf, respectively (Fig. 3). Spacing between crevasses in these groups is roughly $2 \mathrm{~km}$.

Three groups of crevasses, averaging about $120 \mathrm{~m}$ in height, first appear in the data at locations 2,5 , and 8 . The spacing between crevasses in these fields is about $1 \mathrm{~km}$. Group 4 is an independent set of crevasses that overlaps remnants of group 2. (We recognize groups 4 and 2 as distinct sets because the heaviest concentration of crevasses in group 4 does not occur downstream of the heaviest concentration in group 2.) Group 6 is almost directly down-stream of group 4, which suggests that they may be related, but there is a discontinuity in density and general appearance between the two groups. The group 8 crevasses have a singular appearance. in that the crevasses are largest when first observed but the hyperbolas are rather weak. On the succeeding flight line, the diffractions have become diffuse, elongated and dissimilar enough from other aging bottom crevasses to suggest that an alternative explanation may be required for these diffractors.

The crevasses of groups 9 and 11 have fairly large heights but the number of crevasses in each group is small. Both 9 and 11 are identified by one or two large upper hyperbolas. In each case, pairs of basal hyperbolas suggest that other crevasses are present but that surface clutter masks the upper hyperbolas. This result is not unexpected if the crevasses are narrow or frozen Jezek (unpublished) has shown that the amplitude of waves diffracted from the bottom corners of a frozen bottom crevasse are larger than the amplitude of waves diffracted from the apex of a frozen crevasse). There is a suggestion of bottom crevasses at 10. However, severe surface crevassing makes the identification of bottom crevasses difficult.

Airborne sounding across the Siple Coast reveals no crevasses or brine layers comparable to those observed along the grid-eastern coastline. One surface survey carried out at H-5 (lat. $6^{\circ} 37^{\prime}$ S., long. $3^{\circ} 5^{\prime} \mathrm{W}$.) did show some large crevasses that probably are associated with shear along the margin of Ice Stream C.

The crevasses in all groups initially appear as bright diffraction hyperbolas. In most cases they are no longer detectable after about $100 \mathrm{~km}$ (about 250 years) of flow down-stream. The disappearance of crevasses is too rapid to be attributable to simple vertical strain, as is shown in the following calculation. The vertical strain-rate, determined by the ice thickness $H$ and surface accumulation $B$ is

$$
\frac{\partial \dot{w}}{\partial z}=-\frac{\dot{B}}{H}
$$

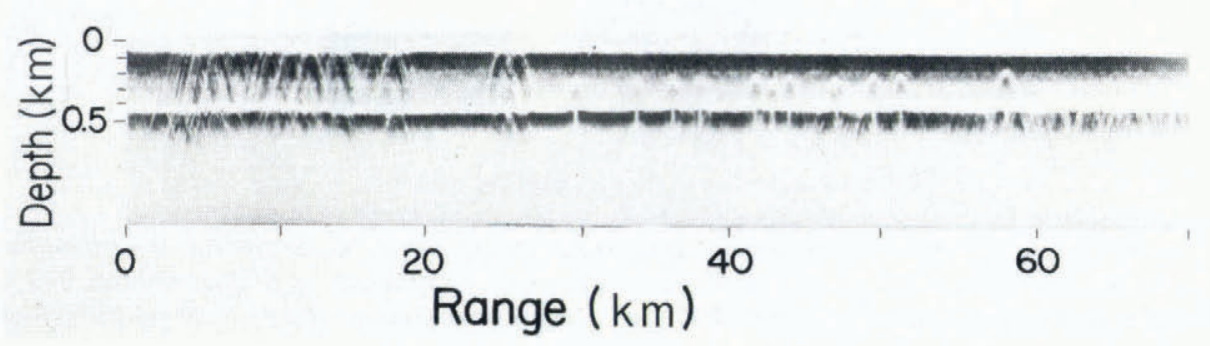

Fig. 3. Section of radar echogram showing the large crevasses in group 7. The coordinates of the left edge of the data are lat. $9^{\circ} 25^{\prime}$ S., long. $1^{\circ} 35^{\prime} \mathrm{W}$. 
where $z$ is the vertical direction and $\dot{w}$ is the component of velocity in the $z$ direction. Integrating Equation (1), we find

$$
\dot{w}=-\frac{\dot{B}}{H} z .
$$

For $z=120 \mathrm{~m}, \dot{B}=0.1 \mathrm{~m} /$ year, and $H=420 \mathrm{~m}, \dot{w}=9 \mathrm{~m}$ in 300 years. This shows that the disappearance of the crevasses cannot be attributed to simple burial. Weertman (1980) has concluded that bottom crevasses remain open due to creep deformation long after their formation; this would suggest that crevasses on the ice shelf have only begun to form in the last few hundred years. A more likely explanation, however, is that the crevasses we have studied have become undetectable because they have frozen closed.

Examples of radar profiles collected on the surface at remote RIGGS stations are presented in Figure 4. Note the difference in diffraction patterns and strength-in particular the weak upper hyperbola and strong lower hyperbolas at N-5 (lat. $9^{\circ} 29^{\prime} \mathrm{S}$., long. $4^{\circ} \mathrm{W}$.) and the roughly concentric hyperbolas at $\mathrm{H}-12$ (lat. $6^{\circ} 15^{\prime} \mathrm{S}$., long. $0^{\circ} 21^{\prime}$ E.). A careful examination of the airborne data also shows that there are some very weak hyperbolas present down-stream of the crevasses formed along the East Antarctic coastline. Some of these have a series of smaller, concentric hyperbolas within them. We believe that the weak returns come from frozen crevasses which in some cases contain isolated pockets of brine causing the concentric hyperbolas to appear.

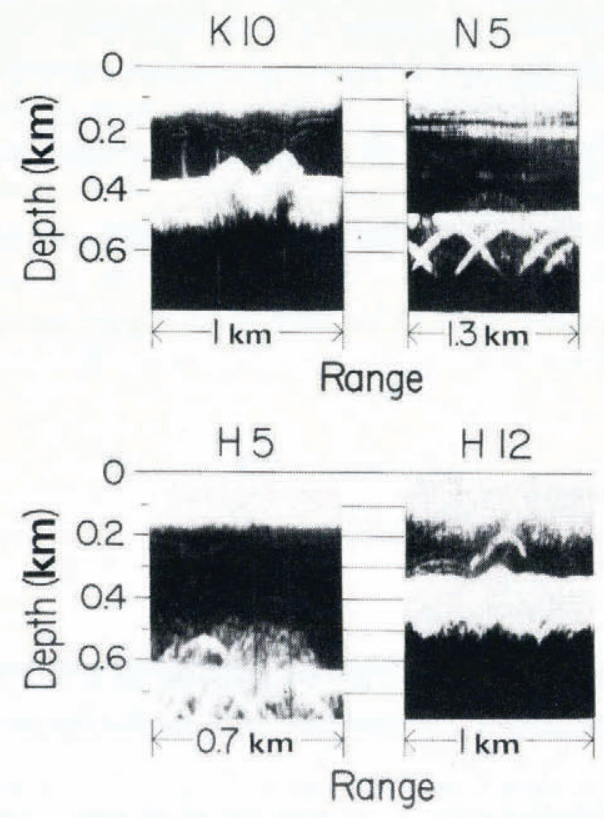

Fig. 4. Examples of bottom crevasses found by radar-profiling experiments conducted on the ice-shelf surface. The weak returns at $\mathrm{N}-5$ (lat. $9^{\circ} 29^{\prime} \mathrm{S}$., long. $4^{\circ} \mathrm{W}$.) are interpreted as diffractions off frozen crevasses. The multiple hyperbolas at $\mathrm{H}-12$ (lat. $6^{\circ} 15^{\prime} \mathrm{S}$., long. $\mathrm{O}^{\circ} 21^{\prime} \mathrm{E}$.) may be caused by crevasses that are only partially frozen. The data at H-5 (lat. $6^{\circ} 37^{\prime} \mathrm{S}$., long. $3^{\circ} 5^{\prime} \mathrm{W}$.) show one of the few recorded examples of crevasses along the West Antarctic grounding line. We suspect the curious features at $\mathrm{K}-10$ (lat. $8^{\circ} \mathrm{S}$., long. $0^{\circ} 57^{\prime} \mathrm{W}$.) to be bottom crevasses but their appearance suggests that they have been deformed. 
Since the determination of whether or not bottom crevasses freeze is crucial to later arguments, Jezek (unpublished) compared amplitude data on bottom crevasses with models of the amplitudes of waves diffracted off the apex and bottom corners of liquid-filled and frozen bottom crevasses. He found that for crevasses similar to those at J9 (Jezek and others, 1978) the amplitude of arrivals from the apex should be about $20 \mathrm{~dB}$ less than the reflection from the bottom of the ice shelf if the crevasse is liquid filled. For crevasses filled with frozen brine, having a salinity similar to that found for the ice frozen to the base of the ice shelf at $\mathrm{J}$, the amplitude of the wave diffracted from the apex of the crevasse is $60 \mathrm{~dB}$ less than the bottom reflection. Although the latter amplitude level should be detectable by the receiver, the small dynamic range of the film ( 10 to $20 \mathrm{~dB}$ ) would inhibit the detection of the weaker signals when the film is used to record intensity-modulated osilloscope displays.

\section{RESULTS}

We believe that most bottom crevasse fields are associated with rapid grounding or ungrounding of ice. This seems to be true of the large crevasses that form along the East Antarctic grounding line and also of the large bottom crevasses (group 3) near Crary Ice Rise. The group 4 crevasses probably form in reponse to shear stress on the ice flowing past Crary Ice Rise. Group 4 does not extend to the boundary of Crary Ice Rise; compression of ice as it is diverted around the ice rise may prevent crevasse formation. The airborne radar data do not reveal any significant groups of bottom crevasses or absorption layers along the Siple Coast, suggesting that the more gentle bottom slope may allow tidal stresses to be dissipated over larger areas.

We will show that most of the other grid-western bottom-crevasse fields form as a response of the ice to previously unidentified ice rises. The existence of numerous small ice rises has been postulated on the basis of qualitative observations of surface topography. In particular, Thomas and Bentley (1978) report considerable surface topography to the grid north-west of both Crary Ice Rise and Steershead Crevasses (about lat. $8 \frac{1}{2}^{\circ} \mathrm{S}$., long. $2 \frac{1}{2}^{\circ} \mathrm{W}$.). We believe that through a combination of data, we can locate six new ice rises on the ice shelf.

As a first step toward locating ice rises, we assume that bottom crevasses form when the ice shelf becomes grounded. Crevasses open as a result of shear stress exerted on the ice as it encounters the ice rise. To differentiate between bottom crevasses formed at ice rises and those which may have other explanations, we begin by examining the water-layer thickness.

If ice rises are indeed causing the formation of bottom crevasses, then there should be some indication of their presence in the ocean bottom topography. Figure 5 is a contour map of waterlayer thickness, determined by subtracting ice thickness from seismically determined depths to ocean bottom, and shows thin water running along the Siple Coast and out along two prongs which reflect suboceanic ridges (Robertson, unpublished). The positions of most of the ice rises, represented by dashed outlines, fall within the $50 \mathrm{~m}$ contour line and, in fact, both $\mathrm{A}$ and $\mathrm{C}$ have confirmed zero water-layer thickness values. Ice rises D, E, and F are all located near RIGGS stations where water-layer thicknesses of $10 \mathrm{~m}$ or less were measured. Moreover, RIGGS field parties noted strand cracks at a station just south-east of D. The water layer is generally thin at $\mathrm{B}$ where a locally-elevated ice surface shows up on the radar data.

Ice rise $G$ is located near somewhat deeper water but is still over an oceanic ridge. The gradient of water-layer thickness around $\mathrm{G}$ determined from the measured stations is very steep. suggesting the water layer near $\mathrm{G}$ could pinch out. 


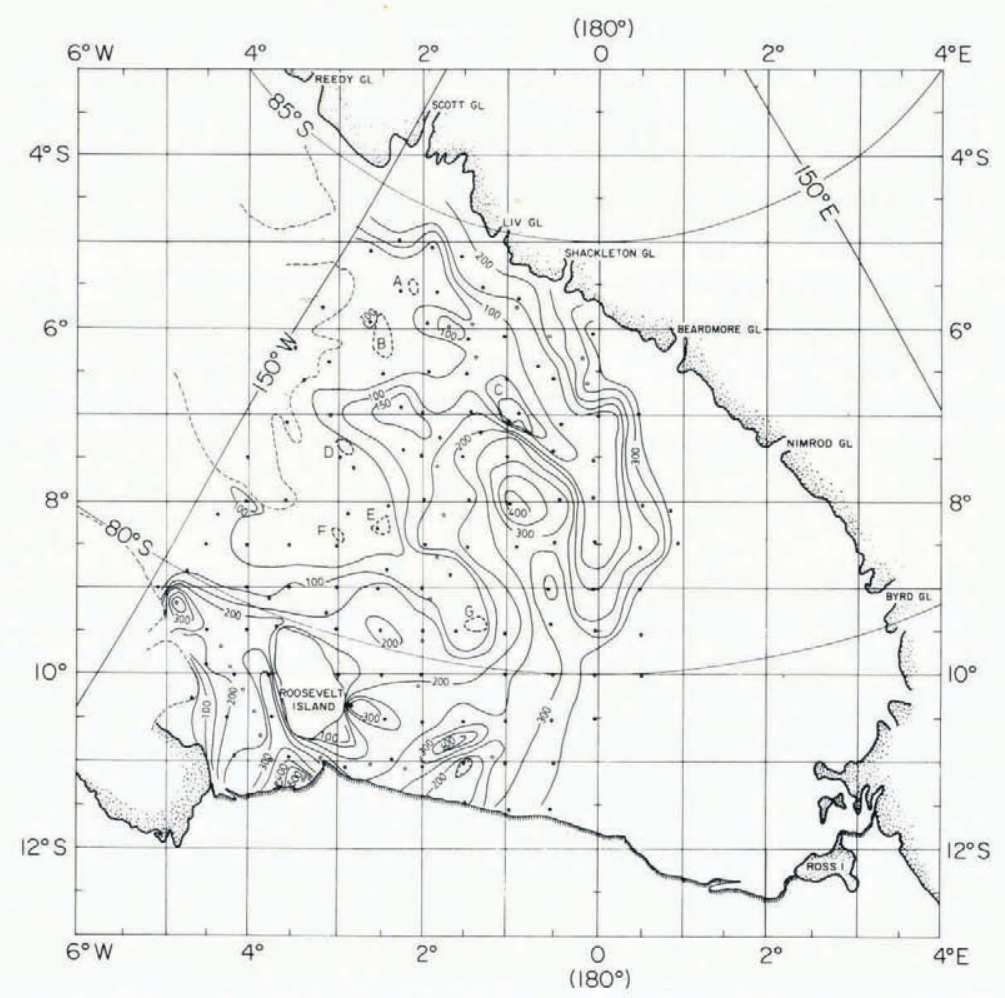

Fig. 5. Water-layer thickness in the western sector of the Ross Ice Shelf. Contours are labeled every $100 \mathrm{~m}$ except for the $150 \mathrm{~m}$ contour in the grid-west central part of the map. The seven ice rises are indicated by letters and dashed lines. The dots represent the locations of water-layer measurements from RIGGS and also from the 1957-58 Ross Ice Shelf traverse (Crary and others, 1962).

Grounded ice may affect ice thickness contours both up-stream and down-stream from an ice rise. Ice thickness contours shown in Figure 6 indicated that up-stream of ice rises A, C, E, and, possibly, D, there is marked thickening of the ice. Ice rises B, C, E, and G all show downstream thinning but this effect may be masked down-stream of $\mathrm{A}$ and $\mathrm{D}$ because they are upstream of $\mathrm{C}$ and $\mathrm{E}$.

We have tried to correlate surface crevassing with ice rises. In all cases we find evidence for crevassing down-stream from the proposed ice rises but the data are sparse and we believe only weakly support our conclusions.

There are two groups of bottom crevasses that cannot easily be associated with grounding points. Group 5 is found over deep water and there is no evidence for grounding up-stream. It is associated with the outflow of Ice Stream C, but it is difficult to relate these crevasses to shear along the margins of the ice stream.

There is some reason to suspect that group 8 may be associated with a nearby ice rise. It is associated with an oceanic ridge even though the water-layer measurements nearby indicate generally deep water. However, detailed examinations of ice thickness patterns in the area (Jezek, unpublished) suggest that group 8 is more likely related to events around Crary Ice Rise.

Finally, we point out that there is not necessarily a dramatic change in surface elevation 


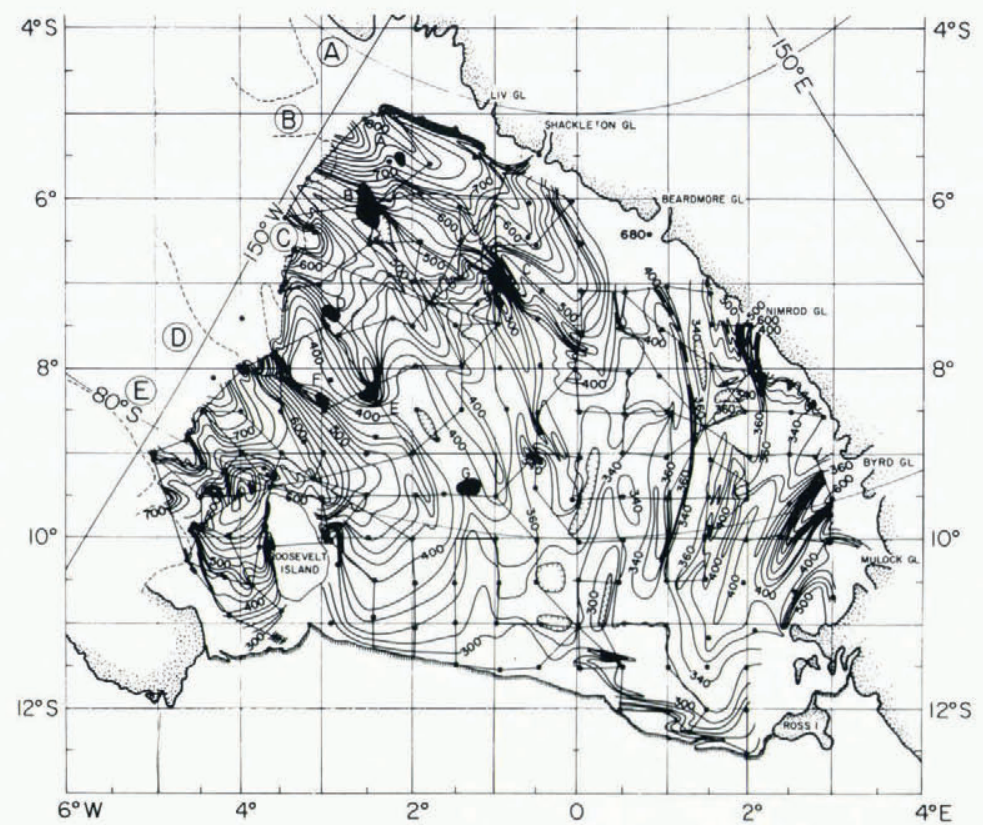

Fig. 6. Ice thickness contours and the locations of the seven ice rises (including Crary Ice Rise). The ice rises are shown as the blackened areas on the map and are identified by letters.

associated with ice-shelf grounding. Radar sounding data collected by Swithinbank on the Ronne Ice Shelf show an instance of a marked change in ice thickness as the ice shelf goes aground, along with bottom-crevasse formation down-stream, but with little surface topography (Swithinbank, 1977 and a personal communication 1981).

\section{SUMMARY OF BOTTOM CREVASSE RESULTS}

Based on the distribution of bottom and surface crevasses, and on patterns of water-layer thickness and ice thickness, we have postulated the existence of six ice rises in the western Ross Ice Shelf. The presence of scattered ice rises accounts for some of the otherwise unexplained changes in the ice-shelf thickness. Not all of the bottom-crevasse fields can be associated with ice rises, which suggests that there are tensions exerted on the ice in some other way.

\section{ACKNOWLEDGEMENT}

This research was supported by National Science Foundation grant DPP79-20736. 


\section{REFERENCES}

Clough, J. W. 1974. RISP radio-echo soundings. Antarctic Journal of the United States, Vol. 9, No. 4, p. 159.

Crary, A. P., and others. 1962. Glaciological studies of the Ross Ice Shelf, Antarctica, 1957-1960, by A. P. Crary, E. S. Robinson, H. F. Bennett, and W. W. Boyd, Jr. IGY Glaciological Report Series (New York), No. 6.

Jezek, K. C. Unpublished. Radar investigations of the Ross Ice Shelf, Antarctica. [Ph.D. thesis, Geophysical and Polar Research Center, University of Wisconsin-Madison, 1980.]

Jezek, K. C., and others. 1979. Electromagnetic sounding of bottom crevasses on the Ross Ice Shelf, Antarctica, by

K. C. Jezek, C. R. Bentley, and J. W. Clough. Journal of Glaciology, Vol. 24, No. 90, p. 321-30.

Neal, C. S. 1979. The dynamics of the Ross Ice Shelf revealed by radio echo-sounding. Journal of Glaciology, Vol. 24, No. 90, p. 295-307.

Robertson, J. D. Unpublished. Geophysical studies on the Ross Ice Shelf, Antarctica. [Ph.D. thesis, Geophysical and Polar Research Center, University of Wisconsin-Madison, 1975.]

Swithinbank, C. W. M. 1977. Glaciological research in the Antarctic Peninsula. Philosophical Transactions of the Royal Society of London, Ser. B, Vol. 279, No. 963, p. 161-83.

Thomas, R. H., and Bentley, C. R. 1978. The equilibrium state of the eastern half of the Ross Ice Shelf. Journal of Glaciology, Vol. 20, No. 84, p. 509-18.

Weertman, J. 1980. Bottom crevasses. Journal of Glaciology, Vol. 25, No. 91, p. 185-88. 